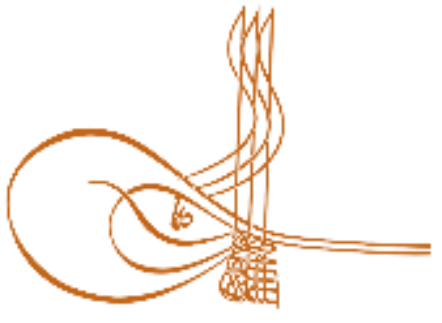

www.turkishstudies.net/social
Turkish Studies - Social Sciences

eISSN: $2667-5617$

Research Article / Araşttrma Makalesi

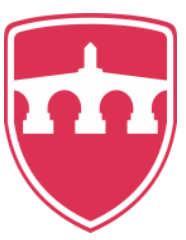

INTERNATIONAL

BALKAN

UNIVERSITY

Sponsored by IBU

\title{
Çevreci Tüketime Yönelik Sosyal Pazarlama Kampanyalarında Bölümlendirme Kriteri Olarak Yaş
}

\author{
Age as a Segmentation Tool for Social Marketing Campaigns for Promoting Pro-Environmental \\ Consumption
}

\author{
İnci Dursun*
}

\begin{abstract}
Social marketing is an efficient approach that is used to increase the number of environmentally conscious, knowledgeable, and active consumers. The approach requires segmentation of the target audience and the development of strategies specific to each target audience in order to create a voluntary behavior change. Among others, age appears as an easy-to-use segmentation criterion for commercial and various social marketing campaigns. However social marketers need to know whether age is a efficient segmentation variable for also social marketing campaigns that are particularly designed for promoting pro-environmental consumption. In this context, efficiency of age to divide the target audiences into groups with differing the intensity of environmentally friendly or environmentally harmful behaviors an attitudes need to be evaluated. As a response to this need this research focused on exploring the existing empirical findings regarding the relationship between the ages of Turkish consumers and their pro-environmental attitudes and behaviors and revealing the nature of the relationship. For the purpose, national publications examining the relation of Turkish consumers' age to their feelings, thoughts, and behaviors related to environmental consumption were reviewed systematically, and their findings were compiled. Although there are some rarely contradictory findings, environmental values, attitudes, and general and specific pro-environmental consumption practices (such as energy-saving, voluntary simplicity) were concluded to be related to age. Moreover, results reveal that proenvironmental attitudes and behaviors of Turkish consumers are positively related to their age, indicating that younger consumers are less likely to engage in general or some specific forms of pro-environmental consumption. According to the reported results of national research, it is safe to conclude that age can be used as an efficient segmentation tool for social marketing campaigns that will be used to build and maintain more environmentally conscious consumption habits in Turkey. Finally, potential explanations for the reluctancy of young consumers to engage in pro-environmental consumption practices are discussed, and recommendations for future research are provided.
\end{abstract}

Structured Abstract: Social marketing refers to "the adaptation of commercial marketing technologies to programs designed to influence the voluntary behavior of target audiences to improve their personal welfare

\footnotetext{
${ }^{*}$ Dr., Gebze Teknik Üniversitesi, İşletme Fakültesi, İşletme Bölümü

PhD., Gebze Technical University, Faculty of Business Administration, Department of Management ORCID 0000-0002-9856-3914

incidursun@gtu.edu.tr

Cite as/ Atıf: Dursun, İ. (2020). Çevreci tüketime yönelik sosyal pazarlama kampanyalarında bölümlendirme kriteri olarak yaş, Turkish Studies - Social, 15(2), 185-200. https://dx.doi.org/10.29228/TurkishStudies.40036

Received/Geliş: 06 December/Aralık 2019

Accepted/Kabul: 25 February/Şubat 2020

Checked by plagiarism software

Copyright $(C)$ INTAC LTD, Turkey 
and that of the society of which they are a part" (Andreasen, 1994:110). It is suggested as an efficient approach to promote sustainable consumption patterns (Frame and Newton, 2007; McKenzie-Mohr, 1994). For social marketing strategies, the segmentation of the audience and exploring the barriers, cost, and motivation sources related to the target behavior for specific target audiences are vital (Lee and Kotler, 2016). At this point, age is considered as an easy-to-use segmentation criterion for social marketing campaigns. However, social marketing practitioners also need to understand whether age is a sufficient criterion for segmenting audiences in pro-environmental consumption context. For this purpose, they evaluate the efficiency of age to divide the target audiences into groups with differing the intensity of environmentally friendly or environmentally harmful behaviors, the strength of environmental values, the perceived barriers to environmental behavior, the perceived benefit of environmental behavior. Research findings on the subject provide some clues regarding how effective age can be as a segmentation criterion in social marketing campaigns for environmental consumption.

In the international literature, findings on the relation of age to environmental behavior have changed over time (Diamantopoulos, Schlegelmilch, Sinkovics, and Bohlen, 2003). Recent findings suggest that although young consumers are more concerned about the environment than older consumers, they are more reluctant in engaging environmental behaviors (e.g., Hellevik, 2002; Wray-Lake, Flanagan, and Osgood, 2010). Although age has been frequently investigated as one of the demographic factors affecting environmental consumption in Turkey, no research has been found to examine the respective findings in a holistic way. In this context, this research aims to review the findings of national papers investigating the relationship of environmental values, beliefs, and behaviors of Turkish consumers with age. In this way, the study aims to assess the effectiveness of age as a segmentation variable in social marketing campaigns designed for promoting pro-environmental consumption in Turkey.

For the research, empirical studies on environmental attitudes and behaviors of Turkish consumers in the national literature were searched in Google academic and DergiPark databases by using keywords such as "pro-environmental consumption", "green consumption", "sustainable consumption" and so on. Among the studies with heterogeneous sample groups, studies that focused on the relationship between environmental consumption and age (or generation) are selected, and their related findings are summarized.

The findings of Turkish studies are found to be consistent with the findings of international research that were conducted after the 2000s. Accordingly, environmental attitudes and behaviors of Turkish consumers are positively related to their age, indicating that younger consumers are less likely to engage in general or some specific forms of pro-environmental consumption. The findings show that age can be used as an efficient target segmentation tool for social marketing campaigns that will be used to build and maintain more environmentally conscious consumption habits. In particular, young consumers age between 15-24, which constitutes $16 \%$ of the population in Turkey (TUIK, 2018), appear as a significant target audience for behavior change programs. Although they got various forms of environmental education within their formal education and also they are exposed to communication campaigns organized by governmental and non-governmental organizations it is observed that the environmental consumption tendency of this young consumer group is weaker compared to older consumers. It is possibly because this group (1) has had relatively little contact with nature in the past and present and consequently having difficulties in forming emotional ties with nature,(2) has weaker altruistic values but stronger egoistic and materialist values, (3) has difficulty in accepting responsibility for solving environmental problems, (4) are relatively less affected by individual and social norms and (5) do not find it rational to loss the comfort, or suffer more from additional effort and time that is perceived to be necessary for environmental behaviors. For an effective social marketing campaign, it is also vital to carefully identify some other specific barriers, the benefits expected from environmental consumption behaviors, sources of motivation, competing behaviors, and influential communication actors through researches on this specific target group of young people (Lee and Kotler, 2016).

Keywords: Pro-environmental consumption, sustainable consumption, social marketing, age, young consumers

Öz: Çevreye duyarlı, bilgili ve aktif tüketicilerin sayısını artırmaya yönelik hedeflere ulaşmada etkili yaklaşımlardan biri sosyal pazarlama yaklaşımıdır. Yaklaşım, tüketicilerde gönüllü davranış değişikliği yaratabilmek için hedef kitlenin bölümlendirilmesini ve her hedef kitleye özel stratejilerin geliştirilmesini gerektirmektedir. Birçok bölümlendirme kriterlerinden biri olan yaş ticari pazarlama ve farklı amaçlarla

Turkish Studies - Social, 15(2) 
tasarlanan sosyal pazarlama kampanyaları için kullanımı kolay bir bölümlendirme kriteri olarak öne çıkmaktadır. Bununla birlikte, sosyal pazarlamacıların, yaşın çevreci tüketimi teşvik etmek için tasarlanmış sosyal pazarlama kampanyaları için de etkili bir segmentasyon değişkeni olup olmadığını bilmesi gerekmektedir. Bu bağlamda, yaşın tüketicileri çevre dostu veya çevreye zararlı davranışlarının sıklığına ve çevreci tutumların gücüne göre faklı gruplara ayırabilecek bir kriter olup olmadığı değerlendirilmelidir. Bu ihtiyaca belirli düzeyde cevap verebilemek için bu araştırma, Türk tüketicilerinin yaşları ile çevreci tutum ve davranışları arasındaki ilişkiye dair mevcut ampirik bulguların incelenmesini ve ilişsinin doğasının ortaya çıkarılmasını amaçlamaktadır. Amaca yönelik olarak Türk tüketicilerinin çevreci tüketim ile ilgili duygu, düşünce ve davranışlarının yaş ile ilişkisini inceleyen ulusal yayınlar taranmış ve bulguları derlenmiştir. Nadiren çelişen bulgulara rastlanmakla birlikte genel olarak çevreci değerlerin, tutumların, genel ve özel (enerji tasarrufu, gönüllü sadelik vb) çevre duyarlı tüketim eğilimlerinin yaş ile ilişkili olduğu anlaşılmaktadır. Bulgular ayrıca Türk tüketicilerinin yaşları ile çevreci tüketim eğilimleri arasındaki ilişkinin yönünün pozitif olduğunu, diğer bir ifade ile genç tüketicilerin, çevreci tüketim konusunda ileri yaştaki tüketicilere nazaran daha gönülsüz olduklarını göstermektedir. Ulusal araştırmalarda raporlanan sonuçlar dikkate alınarak yaşın, Türkiye'de çevreci tüketimi desteklemeye yönelik düzenlenecek sosyal pazarlama kampanyaları için uygun bir bölümlendirme kriteri olduğu sonucuna varmak mümkündür. Araştırmada son olarak, çevreci tüketim eğilimlerinin gençlerde daha düşük olmasının olası nedenleri tartışılmış, gelecek araştırmalar için öneriler sunulmuştur.

Anahtar Kelimeler: Çevreci tüketim, sürdürülebilir tüketim, sosyal pazarlama, yaş, genç tüketiciler

\section{Giriş}

Dönemin gelişim, üretim ve tüketim şekillerinin ne kadar sürdürülebilir olduğunun sorgulanmaya başladığı 1970'li yıllar ve sonrasında üzerinde fikir birliğine varılan konu, oluşan çevre sorunlarının çözümünde bireylerin tüketime ilişkin tercih ve davranışlarının önemli bir rol oynadığıdır. Bu sebeple, uzun vadeli "kaliteli çevre" hedefine ulaşmada bireysel tüketicilerin çevre koruma amacını ortak hedef olarak benimsemelerini, çevre koruma konusunda eğitimli ve aktif olmalarını sağlamak kritik öneme sahiptir (Tanner, 1980). Kırk yılı aşkın bir süredir farklı disiplinlerde yürütülen sayısız araştırma, tüketicilerin çevre dostu ve/veya çevreye zararlı tüketim davranışlarını açıklamaya odaklanmıştır. Diğer taraftan, hükümetler ve sivil toplum kuruluşları elde edilen bilimsel bulgulardan da faydalanarak tüketicilerin çevreye ve topluma zararlı davranışlarının değiştirilmesine yönelik çalışmalar yürütmektedir.

Tüketicilere sürdürülebilir davranışların benimsetilmesi noktasında kullanılan yaklaşımlardan biri, hedef kitlede hayat kalitesini artıracak gönüllü davranış değişiklikleri yaratmak için ticari pazarlamanın prensip ve yeteneklerinin kullanılması olarak tarif edilen (Andreasen, 1994) sosyal pazarlama yaklaşımıdır (örn. Frame ve Newton, 2007; McKenzie-Mohr, 1994). Sosyal pazarlama yaklaşımını geleneksel iletişim kampanyalarından ayıran en önemli özelliklerinden biri davranış değişikliği yaratılmak istenen kitlenin belirli kriterlere göre bölümlendirilerek, hedef alınan her bölüm için ayrı ayrı pazarlama stratejisi geliştirilmesidir (Bakınız Lee ve Kotler, 2016). Uygulamacılar bölümlendirme sürecinde farklı kriterlerden faydalanılabilmektedir. Yaş, çevreci tüketimi desteklemeye yönelik sosyal pazarlama kampanyaları için yeterince büyük ve ulaşılabilir hedef kitleler tanımlamada faydalanılabilecek, kullanımı kolay bir bölümlendirme kriteri olarak öne çıkmaktadır. Ancak burada akla gelen kritik soru, yaşın hedef kitleyi çevreci tüketim bağlamında tepkileri, niyetleri, davranışları ayrışan bölümlere ayırmada yeterli olup olmayacağıdır. Bu durumun değerlendirilebilmesi için yaşın çevreci tutum ve davranışlarla ne kadar yakından ilişkili olduğunun bilinmesi gereklidir. Neredeyse yarım yüzyıldır yapılan sayısız ampirik araştırmanın, yaşın çevreci tutum ve davranışlarla ilişkisine dair sunduğu bulgular konuya ilişkin karar vermeyi kolaylaştırmaktadır.

Uluslararası literatür incelendiğinde, yaş ile çevreci davranışlar arasında bir ilişkinin söz konusu olduğu ancak bu ilişkinin doğasının zaman içinde değişiklik gösterdiği dikkat çekmektedir 
(Diamantopoulos, Schlegelmilch, Sinkovics, ve Bohlen, 2003). Günümüze gelindiğinde bulgular, genç tüketicilerin ileri yaşlı tüketicilere oranla daha eğitimli ve daha kaygılı olmalarına rağmen çevreci davranışları sergilemede daha gönülsüz ve pasif oldukları yönündedir (örn. Hellevik, 2002; Wray-Lake, Flanagan, ve Osgood, 2010). Bu durum yaşın, en azından uluslarası platformda çevreci tüketime yönelik sosyal pazalama kampanyalarında kullanılabilecek etkili bölümlendirme kriterlerinden biri olduğunu göstermektedir. Diğer taraftan bu bulgular özellikle genç tüketicilerin toplum için planlanan uzun dönemli sosyal değişimin gerçekleştirilmesinde kritik öneme sahip bir hedef kitle olduğuna işaret etmektedir.

Konuya ilişkin ulusal literatür incelendiğinde ise yaş-çevreci tüketim ilişkisini inceleyen çalışmaların olduğu ancak bulguların bütüncül şekilde irdelendiği bir araştırmanın bulunmadığı görülmüştür. $\mathrm{Bu}$ kapsamda bu araştırmanın ilk amacı, ülkemizde yaşın çevreci tüketimi desteklemeye yönelik sosyal pazarlama kampanyalarında bölümlendirme kriteri olarak kullanımının uygunluğunu değerlendirebilmek için Türk tüketicilerin çevreci tüketime ilişkin bilgi, düşünce ve davranışlarının yaş ile ilişkisini araştıran ulusal yayınların bulgularının derlenmesidir. Diğer bir amaç ise yaş-çevreci tüketim ilişkisinin temel dinamiklerinin, özellikle de genç tüketicilerin tutum ve davranışlarının daha ileri yaşlı tüketicilerden neden ve nasıl ayrıştığının tartışılmasıdır. Böylece, gelecek araştırmalara ve Türk tüketicilerine (özellikle gençlere) yönelik düzenlenecek sürdürülebilir tüketimi destekleme amaçlı sosyal pazarlama kampanyalarına katkı sağlamak hedeflenmektedir.

\section{Literatür Taraması}

Wiebe (1952) tarafindan toplumsal olguların da ticari ürün ve hizmetler gibi pazarlanabileceği görüşünün öne sürülmesi ile 1970'li yılların başlarında pazarlama yönetiminin sınırları, adeta dünyayı daha iyi bir yer haline getirmede oynayabileceği rolünün eklenmesi ile genişlemiş ve böylece sosyal pazarlama kavramı doğmuştur (Kotler ve Levy, 1969; Kotler ve Zaltman, 1971). Sosyal pazarlamadaki temel fikir; pazarlamanın, tüketicileri belirli bir ürünü, hizmeti, markayı alma konusunda etkileyebildiği gibi onları kendi hayatlarını ve toplumdaki diğer bireylerin hayatlarını iyileştirecek davranışları benimsenmeleri noktasında da destekleyebilecek olmasıdır (MacFadyen, Stead, ve Hastings, 1999). Pazarlama disiplini, pazarlamaya önerilen bu yeni ve özel görevi benimsemiş, sosyal pazarlama kavramı, hakkında yazılan bilimsel makaleler, referans kitapları ve bilimsel kitaplar ile disiplin içindeki yerini almıştır. Sosyal pazarlama yalnızca akademik alanda değil aynı zamanda uygulama alanında da kabul görmüş, devlete bağlı ve bağlı olmayan birçok kurum ve organizasyon tarafından benimsenmiştir (Andreasen, 2002). Yaklaşım bireysel, toplumsal ve çevresel fayda için mikro ve makro düzeydeki birçok konuda başarı ile uygulanmıştır. Kabaca, toplumsal refah, sağlık, eğitim ve çevre olmak üzere dört uygulama alanında; yolcuları tren raylarından uzak tutmak, gıda israfinı azaltmak, kanser araştırmaları için bağış sağlamak, sosyal yenilikçilik içeren girişimleri artırmak, tatil yolculuklarını daha güvenli hale getirmek, vergi kaçırmayı engellemek, bulaşıcı hastalıklardan korunmak için el yıkama alışkanlığı kazandırmak, obeziteyle mücadele kapmsamında yemek porsiyonlarını küçültmek, daha sağlıklı ve dengeli beslenmeyi desteklemek, bisiklet kullanımını artırmak, karbon nötrilitesi sağlamak, kıyı şeridi temizlik akımı başlatmak, sokaklara çöp atmayı engellemek, okyanus okuryazarlığını artırmak, kadın işgücünü desteklemek gibi amaçlarla sosyal pazarlama kampanyaları düzenlenmiştir (dünyadan uygulama örnekleri için bakınız Basil, Diaz-Meneses ve Basil, 2019; Cheng, Kotler ve Lee, 2011). Bazı örnekleri yukarıda verildiği gibi, sosyal pazarlama yoğun olarak medya reklamlarına dayanan geleneksel bilgi yoğun iletişim kampanyalarının davranışları değiştirmede yeterli olamadığı (McKenzie-Mohr, 2000) çevreci tüketim alanında da büyük bir etki potansiyeline sahiptir. Ancak bunun için sosyal pazarlamayı iletişim kapmanyalarından ayıran temel farkların bilinmesi gereklidir.

Ticari pazarlama yöntemlerinin, hedef kitlede gönüllü davranış değişikliği yaratmak üzere tasarlanan programlara uygulanması olarak tanımlanan sosyal pazarlama (Andreasen, 1994:110) sosyal değişim için sürdürülen çabaları, hedef kitlede beklenen etkiyi yaratacak daha etkili bir şekilde 
tasarlanmış ve tanıtılmış programlara dönüştürmektedir (Kotler ve Zaltman, 1971:3). Bunu yaparken ticari pazarlamada olduğu gibi; tüketici odaklı araştırma, pazar analizi, pazarın bölümlendirilmesi, amaçların belirlenmesi ve bu amaçlara yönelik strateji ve taktiklerin geliştirilmesini içeren bir planlama süreci kullanılmaktadır (MacFadyen, Stead ve Hastings, 1999). Lee ve Kotler (2016)'e göre toplamda on aşamadan oluştuğu belirtilen bu planlama süreci içinde bölümlendirme aşaması kritik bir önem taşımaktadır. Yazarlara göre bölümlendirmenin amacı hedef kitleyi, davranış değişikliği yaratmak için farklı ikna stratejilerinin kullanımını gerektirecek kadar birbirinden farklılaşan gruplara ayırmaktır. Her bir grup kendi içinde ihtiyaç, istek, hedeflenen davranışa ilişsin engeller, motivasyonlar, değerler, davranış ve hayat tarzı açısından birbirine benzer özellik taşıyan, bu sebeple ikna mesajlarına benzer tepkiler vermesi beklenen üyelerden oluşmalıdır (Lee ve Kotler; 2016). Bölümlendirme ile hedef kitleye özelliklerine, şimdiki davranışlarına, tercihlerine, beklentilerine uygun davranış önerileri sunmak ve gruplara özel etkili iletilişim mesajları geliştirmek mümkün olacaktır (Lefebvre, 2013).

Ticari pazarlamada bölümlendirme kriteri olarak kullanılan demografik, coğrafi, psikografik ve davranışsal özellikler sosyal pazarlama kampanyalarında da kullanılmaktadır. Bu kriterlerden biri de kullanımı oldukça kolay olan yaştır. Yaşın çevreci tüketime yönelik sosyal pazarlama kampanyalarında kullanılabilecek etkili bir bölümlendirme kriteri olup olmadığını anlamak için bazı kriterler mevcuttur. Buna göre yaşın, hem çevreci veya çevreye zararlı davranışların yoğunluğu, çevreci değerlerin gücü, çevreci davranma önünde alglanan engeller, çevreci davranışa dair algılanan fayda açısından farklılaşan, hem de ikna mesajları ile ulaşılabilecek, davranışları değiştirilebilecek, anlamlı büyüklüğe sahip tüketici grupları oluşturmadaki yeterliliği sorgulanmalıdır (Bakınız Lee ve Kotler; 2016). Konuya ilişkin bilimsel araştırma bulguları, yaşın bir bölümlendirme kriteri olarak çevreci tüketime yönelik sosyal pazarlama kampanyanlarında ne kadar etkili olabileceğine yönelik bazı ipuçları sunmaktadır.

\section{Yaş ve Çevreci Tüketim İlişkisi}

Tüketim ve üretim sistemlerinin çevreye zararlarının sorgulanmaya başladığ 1970'li yıllar ve sonrasındaki ilk 25 yılda yapılan araştırmalarda ağırlıklı olarak, çevreci kaygılar duyan, tüketim kararlarında çevreye verilecek zararı da dikkate alan "yeşil tüketicilerin" profillerinin belirlenmesi üzerinde durulmuştur (Literatür taraması için bakınız Kilbourne ve Beckmann, 1998). Bu çalışmaların önemli bir bölümünde yaş, cinsiyet, medeni hal, çocuk sayısı, eğitim seviyesi, sosyal sınıf gibi sosyo-demografik özelliklerin çevreci tutum ve davranışlarla ilişkisine odaklanılmıştır (Peattie, 2012). Bu faktörlerin etkisine dair bulgulardaki tutarsızlıklar konuya yönelik kesin bir çıarım yapmayı engelleyerek araştırmacıları daha karmaşık modellemelere yöneltmişse de demografik faktörlerden biri olan yaş, hakkındaki nispeten çok daha güçlü ve tutarlı bulgular sebebi ile ayrı bir konumda tutulmuştur (Buttel, 1979; Honnold, 1984; Van Liere ve Dunlap, 1980). Ancak yaş ile çevreci eğilimler arasındaki ilişkinin varlığına yönelik bulgular nispeten tutarlı olsa da bu ilişkinin yönüne dair bulguların zaman itibari ile değişiklik gösterdiği dikkat çekmektedir. Buna göre yaş-çevreci tüketim eğilimleri ilişkisi üç farklı dönemden geçmiştir.

Çevreci davranışların araştırıldığı 1970’li yıllarda yapılan araştımaları derleyen Buttel (1979), bulguların yaş ile çevreci davranışlar arasında negatif yönlü bir ilişkinin varlığına, yani gençlerin ileri yaşlı tüketicilere göre nispeten daha çevre duyarlı olduğuna işaret ettiğini belirtmiştir. Benzer şekilde, Van Liere ve Dunlap (1980) de bir yıl sonra sundukları literatür taramasında, inceledikleri çalışmaların çok büyük bir kısmında tüketicilerin yaşlarının çevreci kaygılarıyla negatif ilişkili bulunduğunu ve bu ilişkinin diğer sosyo-demografik faktörlerden daha güçlü olduğunu vurgulamıştır. Genel olarak değerlendirildiğinde, 1970-1980 yılları arasındaki araştırmalar genç tüketicilerin daha güçlü çevreci kaygılarının olduğuna işaret etmiştir. Bu bulgular, 1960ların sonunda başlayan çevreci hareketin gençler tarafından daha kolay benimsenmesi, 1970'li yılların başında çevrenin alarm veren durumuna ilişkin kitle iletişim aracı mesajlarının ve farklı şekillerde verilmeye 
başlayan çevre eğitimlerinin gençler üzerinde daha kolay etki etmesi ile açıklanmıştır (Buttel, 1979; Honnold, 1984). Gençler, mevcut sosyal düzene daha zayıf entegre olduklarından dolayı, çevre sorunlarının hafifletilmesi için alınan, mevcut sosyal düzenin sorgulanmasını, gelenekselleşmiş değerlerin ve alışkanlıkların ciddi şekilde değişmesini gerektiren önlemleri daha kolay kabul etmiştir (Van Liere ve Dunlap, 1980). Bu araştırmalardan yaklaşık 30 yıl sonra Wiernik, Ones ve Dilchert (2013), bu durumun genç tüketicilerin yeniliğe açık olmaları sebebiyle sürdürülebilir fikirleri daha çabuk benimsemelerinden kaynaklandığını ileri sürmüştür. Yazarların getirdiği diğer bir açıklama ise Sosyo-Duygusal Seçicilik Teorisi'ne dayanmaktadır. Teoriye göre, bireyler önlerindeki hayatın uzunluğunu düşünerek hareket etmektedir ve bu sebeple daha uzun bir ömürleri olduğunu düşünen genç tüketiciler uzak geleceğe dair amaçlarına daha fazla önem vermekte, çevre sorunlarının uzun süre boyunca kendilerini etkilemesini istemediklerinden çevreci davranmaktadır (Wiernik, Ones ve Dilchert; 2013).

Çevreci davranışın norm haline geldiği 1970'li yıllar boyunca yukarıda sunulan bulgular ve açıklamalara da dayanarak genç tüketicilerin daha temiz ve yeşil bir dünya yaratmada öncülük edeceği düşünülmüştür (Diamantopoulos vd., 2003). Ancak ne yazık ki gençlerin çevre sorunlarına yönelik hassasiyetleri ve kaygıları hep aynı düzeyde kalmamış, ilerleyen yıllar itibari ile zayıflamıştır. Honnold (1984) bu zayıflamayı, gençliğinde çevreci kaygılar ile sosyalleşmiş tüketiciler de dahil olmak üzere tüm tüketicilerde görülen yaşlanma sürecine ve dönemin politik rüzgarının etkisine bağlamıştır. Yaşanan bu değişimlerle birlikte yaş ile çevreci eğilimler arasındaki ilişki net ve açık olmaktan uzaklaşmıştır. Örneğin 1987 yılında ABD'de yapılan bir araştırmada; tüketicilerin yaşı ile çevre sorunlarına yönelik dikkatleri, farkındalıkları, çevreye ilişkin bilgi alma amacıyla medya kullanımları, bilgi düzeyleri, kaygı ve çevreci davranışları arasında anlamlı ilişkilerin olmadığı bulunmuştur (Ostman ve Parker, 1987). Hines vd., 1987 yılında çevreci davranış1 açıklamada en etkili bilişsel, psikososyal ve demografik faktörlerin hangileri olduğu sorusuna cevap bulmayı hedefledikleri meta analizlerinde, yaş ile çevreci davranışlar arasında var olduğu ileri sürülen negatif ilişkinin farklılışan bulgular dikkate alındığında temelsiz olduğunu belirtmiştir.

Hines ve arkadaşlarından yaklaşık 20 yıl sonra Diamantopoulos ve çalışma arkadaşlarının (2003), sosyo-demografik faktörlerin çevreci tutum ve davranışlar ile ilişkisine dair ampirik bulguları derledikleri makalelerinde, yaşa ilişkin bulgularda yıllar itibariyle yaşanan dönüşüm açıkça görülmektedir. Buna göre, 1970 ile 1980 yılları arasında yapılan araştırmalarda yaşın çevreci tutumlarla negatif ilişkili olduğu dikkat çekerken, 1980'li yıllarda bu ilişki bulanıklaşmış, 1990'lı yıllara gelindiğinde ise yaşın özellikle çevreci davranışlarla ilişkisinin yönü değişerek pozitife dönmüştür. Diğer bir ifadeyle, 1990'lı y1llardan sonra gençler, 1970'li y1llardaki gençlerin aksine çevreci davranışlarda ileri yaşlı tüketcilere nazaran daha pasif kalmaktadır. Bu bulgu, sonraki birçok araştırmada da desteklenmiştir. Örneğin Diamantopoulos vd. (2003), İngiltere'de yürüttükleri alan araştırmasında, çevreci bilgi ve tutumların genç tüketicilerde nispeten daha güçlü olduğunu, ancak dikkat çekici bir şekilde çevreci davranışlarda tam tersi bir durumun söz konusu olduğunu, gençlerin davranışlarının daha zayıf olduğunu göstermiştir. Benzer şekilde Hellevik (2002) de, Norveç’te 1997-2001 yılları arasındaki trendi incelediğinde genç tüketicilerin çevrenin genel durumu hakkında ileri yaştakilere nazaran çok daha olumsuz görüşleri olduğunu, ancak sıra kişisel çabalara, çevre için fedakarlıkta bulunmaya ve aktif davranışa geldiğinde ileri yaştaki tüketicilerden çok daha gönülsüz olduklarını ortaya çıkarmıştır. Yine Norveç'te 2001 yılında yapılan başka bir araştırmada, tüketicilerin diğer sosyo-demografik özellikleri, çevreci tutum ve bilgileri sabit tutulduğunda, genç tüketicilerin çevre sorumlu tüketim, kaynak tasarrufu, toksik ürünlerden kaçınma, atık azaltma ve doğa ile iç içe olma gibi çevreci davranışları nispeten daha nadir sergiledikleri görülmüştür (Olli, Grendstad, ve Wollebaek, 2001). Bu durum 1970'li y1llarda gençlik yıllarını yaşayan tüketici grubunun çevreci bir nesli temsil ettiği, sonraki yıllarda yaşayan gençlerin ise benzer bir çevreci yaklaşımı benimseyemediği şeklinde yorumlanabilir. 1976-2005 yılları arasında aynı yaş grubundaki Amerikalı genç tüketicilerin çevreci tutum ve davranışlarını karşılaştıran Wray-Lake, Flanagan ve 
Osgood (2010) bu argümanı destekleyecek dikkat çekici bulgulara erişmiştir. Araştırmaya göre; yaklaşık 30 yıllık dönem içinde aynı yaş grubuna dahil tüketici gruplarının kirlilik hakkındaki endişeleri, çevre sorunlarının çözümü için hükümeti ve başkalarının sorumlu tutma seviyelerinde bir değişim olmazken, çözüm için hissettikleri bireysel sorumlulukta düşüş olmuştur. Araştırmanın belki de en önemli bulgusu ise çevreci davranışların sergilenme sıklı̆ındaki dramatik azalmadır. Bulgular net bir şekilde 1980'li yıllardan sonra gençlerin elektrik tasarrufu, yakıt tasarrufu, isınma enerjisi tasarrufu, bisiklet ve toplu taşıma kullanma gibi enerji tasarrufu sağlamaya yönelik çabalarının giderek azaldığını göstermiştir.

Benzer şekilde, 2004 yılında ABD'de yapılan bir araştırmada, birçok diğer faktörün etkisi sabit tutulduğunda yaşın çevreci tutumlar ile negatif, doğa dergileri okuma, geri dönüşüm yapma gibi davranışlarla pozitif ilişkili olduğu bulunmuştur (Johnson, Bowker, ve Cordell, 2004). Diğer bir ifade ile gençler, çevreci bir dünya görüşüne sahip olduklarını belirtmekte ancak bu tercihleri davranışlarına yansımamaktadır. Aynı yöndeki bulguların Avrupa'da yürütülen anket sonuçlarında da çıktığını belirten Grønhøj ve Thøgersen (2009) Danimarka'da yaptıkları araştırmada bu farkı sosyalleşme perspektifinden incelemiştir. Bulgular, çocukların incelemeye alınan çevreci davanışların tamamında (organik gıda satın alma, kaynağında atık ayrıştırma ve enerji tasarrufu) anne-babalarından daha az çaba gösterdiğine işaret etmektedir. Yazarlar bu durumu, çocukların çevreci davranışların algılanan maliyetine yetişkinlerdan daha duyarlı olmaları, bireysel çaba gerektirecek davranışlardan uzak durmaları ile açıklamaktadır.

2013 yılına gelindiğinde, Wiernik vd., 1970-2010 yılları arasındaki araştırmalar üzerinde yaptıkları meta analiziyle, yaşın çevresel kaygı, değer, bağlılık, farkındalık ve niyetler ile net bir ilişkisi olmadığını göstermiştir. Ancak, araştırmanın dikkat çeken bulgularından biri ileri yaştaki tüketicilerin, çevreye zarar vermekten ve kirlilik yaratmaktan kaçınma, ekosistemi aktif olarak koruma ve doğa ile içiçe olma konusunda gençlerden daha etkin olmasıdır. Araştırmanın bir diğer önemli bulgusu da daha ileri yaştaki bireylerin, çevreci davranışlar için pişmanlık hissinden, bireysel ve toplumsal normlardan etkilenme oranının gençlerden daha yoğun gerçekleşmesidir.

Genel olarak bulgular incelendiğinde; 1970'li y1llarda yaşayan gençlerden farklı olarak çevre konusunda eğitimler alan, geleneksel ve sosyal medya aracıllğ̆ ile yoğun şekilde ikna mesajına maruz kalan günümüz genç tüketicilerinin çevreci davranışlar sergilemedeki gönülsüzlüğü dikkat çekmektedir. Ancak bu bulguların tamamı Türkiye dışındaki ülkelerden gelmektedir. Ülkemizde yaş ile çevreci tüketim davranışlarının ilişkisini zaman serimli olarak incelemeye imkan tanıyacak bir panel dataya rastlanmamıştır. Diğer taraftan ülkemizde çevreci tüketim üzerindeki araştırmalar, uluslarası literatürde yaş-çevreci tüketim ilişkisinin doğasının değiştiği 2000'li yıllarda yoğunluk kazanmıştır (literatür taraması için bakınız Dursun ve Gündüz, 2016). Bu sebeple ülkemizde, 1970’li yıllardan günümüze çevreci hareketin nasıl bir gelişim gösterdiğini, yaş-çevreci davranış arasındaki ilişkinin değişime uğrayıp uğramadığını değerlendirmek (en azından dijital kaynaklar ile) mümkün görünmemektedir. Ancak mevcut durumda ülkemizde yaş ile çevreci tutum ve davranışlar arasındaki ilişkinin doğasını anlamak sürdürülebilir tüketime yönelik geliştirilecek politika ve sosyal pazarlama kampanyalarında yaşın etkili bir bölümlendirme kriteri olarak kullanılıp kullanılmayacağının değerlendirilmesi açısından önemlidir.

\section{Yöntem}

Araştırma amaçları doğrultusunda ulusal literatürde yer alan, Türk tüketicilerinin çevreci tutum ve davranışları üzerinde yapılan ampirik araştırmalar belirlenmiştir. Bunun için Google akademik ve DergiPark veri tabanlarında "çevreci tüketim", "yeşil tüketim", "sorumlu tüketim", "bilinçli tüketim”, "sürdürülebilir tüketim”, "enerji tasarrufu”, "geri dönüşüm”, "gönüllü sadelik”, "çevre bilinci”, "çevresel duyarlılık", "çevresel kaygı", "bilinçli tüketici", "yeşil tüketici” vb. anahtar kelimeler kullanılarak aramalar yapılmıştır. Ulaşılan araştırmaların önemli bir kısmının belirli bir yaş grubu (örn. üniversite öğrencileri, Y kuşağı) ile sınırlandığı görülmüş, bu araştırmalar yaş-çevreci 
davranış ilişkisini değerlendirmeye uygun olmadığından tarama listesinden çıkarılmıştır. Yaş itibari ile nispeten heterojen örneklem grubuna sahip çalışmalar arasından çevreci tüketim-yaş (veya kuşak) ilişkisini test eden çalışmalar seçilmiş ve bu araştırmaların bulguları Tablo 1'de özetlenmiştir.

Tablo 1: Türkiye'de Yaş-Çevreci Tutum ve Davranış İlişkini İnceleyen Ampirik Araştırma Bulguları.

\begin{tabular}{|c|c|c|c|c|c|c|}
\hline Yıl & Yazar (lar) & $\begin{array}{l}\text { Çevresel Duyarlılığa İlişkin } \\
\text { Değişkenler }\end{array}$ & $\begin{array}{l}\text { Örneklem } \\
\text { Hacmi }\end{array}$ & $\begin{array}{l}\text { Örneklem } \\
\text { Min/Max Yaş }\end{array}$ & $\begin{array}{l}\text { Kullanılan } \\
\text { Analiz }\end{array}$ & $\begin{array}{l}\text { Yaş İle İlişkinin } \\
\text { Doğası }\end{array}$ \\
\hline 2007 & Nakiboğlu & Çevreci tüketim davranışı & 392 & $20 / 59$ & Kümeleme & + \\
\hline 2009 & Yeşilada & Çevre bilinçli tüketim & 600 & 17 ve üzeri & Korelasyon & + \\
\hline \multirow{3}{*}{2010} & \multirow{3}{*}{ Ayten } & Genel çevreci davranış & \multirow{3}{*}{243} & \multirow{3}{*}{$18 / 76$} & \multirow{3}{*}{ Korelasyon } & + \\
\hline & & Aktif çevre duyarlılığ 1 & & & & + \\
\hline & & İsraftan kaçınma & & & & + \\
\hline \multirow{2}{*}{2010} & \multirow{2}{*}{$\begin{array}{l}\text { Özdemir, } \\
\text { Karaarslan ve } \\
\text { Altuntaş }\end{array}$} & $\begin{array}{l}\text { Çevreyi kirleten işletmeleri } \\
\text { araştırma }\end{array}$ & \multirow{2}{*}{360} & \multirow{2}{*}{$-25 / 35$ ve üzeri } & \multirow{2}{*}{$\mathrm{t}$ testi } & + \\
\hline & & $\begin{array}{l}\text { Pahalı olsa da çevre dostu } \\
\text { ürünleri alma }\end{array}$ & & & & n.s \\
\hline 2011 & \begin{tabular}{|l|l} 
Özgül \\
\end{tabular} & Gönüllü sade yaşam tarzı & 427 & $18 / 50$ ve üzeri & Korelasyon & + \\
\hline 2011 & $\begin{array}{l}\text { Yaraş, Akın ve } \\
\text { Şakacı }\end{array}$ & Çevre bilinci & 399 & $-20 / 60$ ve üzeri & ANOVA & n.s. \\
\hline \multirow{2}{*}{2013} & \multirow{2}{*}{ Karaca } & Cevre dostu ürün satın alma & \multirow{2}{*}{362} & \multirow{2}{*}{$18 / 66$ ve üzeri } & \multirow{2}{*}{ ANOVA } & \multirow{2}{*}{$\begin{array}{l}\text { anlamlı fark: yön } \\
\text { belirtilmemiş }\end{array}$} \\
\hline & & Çevreye duyarlı ürün bilinci & & & & \\
\hline 2013 & Zülfikar & Yeşil ürün-hizmet tercihi & 150 & Belirtilmemiş & $\begin{array}{l}\text { Diskriminant } \\
\text { Analizi }\end{array}$ & n.s \\
\hline \multirow{3}{*}{2014} & \multirow{3}{*}{$\begin{array}{l}\text { Armağan ve } \\
\text { Karatürk }\end{array}$} & Çevreye duyarlı satın alma & \multirow{3}{*}{400} & \multirow{3}{*}{$18 / 66$ ve üzeri } & \multirow{3}{*}{ ANOVA } & - \\
\hline & & Cevreye duyarlı kullanım & & & & n.s \\
\hline & & Çevrecilik & & & & n.s \\
\hline \multirow{4}{*}{2015} & \multirow{4}{*}{ Özsoy ve Madran } & Çevre bilinçli tüketim & \multirow{4}{*}{1815} & \multirow{4}{*}{$20 / 50$ ve üzeri } & \multirow{4}{*}{ ANOVA } & + \\
\hline & & Cevresel değer & & & & + \\
\hline & & Çevresel yetkinlik & & & & n.s \\
\hline & & Çevresel önem & & & & + \\
\hline 2015 & Aksu ve Gelibolu & Çevresel yetkinlik & 513 & Belirtilmemiş & ANOVA & $\begin{array}{l}\text { anlamlı fark: yön } \\
\text { belirtilmemiş }\end{array}$ \\
\hline 2016 & $\begin{array}{l}\text { Şahin, Meral ve } \\
\text { Aytop }\end{array}$ & Yeşil ürün satın alma & 271 & 20/46 ve üzeri & Ki-kare & n.s. \\
\hline \multirow{3}{*}{2016} & \multirow{3}{*}{ Aydın } & Cevreci tüketim-duygusal değer & & & & + \\
\hline & & $\begin{array}{l}\text { Çevreci tüketim-fonksiyonel } \\
\text { değer }\end{array}$ & 391 & $18 / 36$ ve üzeri & Wilks' Lambda & - \\
\hline & & Öz-așkınlık değeri & & & & + \\
\hline & & $\begin{array}{l}\text { Çevreci otel restoranına yönelik } \\
\text { tutum }\end{array}$ & & & & n.s \\
\hline 2016 & Yay ve Çalışkan & $\begin{array}{l}\text { Çevreci otel restoranına yönelik } \\
\text { öznel norm }\end{array}$ & 533 & $25 / 40$ ve üzeri & ANOVA & n.s \\
\hline & & $\begin{array}{l}\text { Çevreci otel restoranı tercihe } \\
\text { yönelik algılanan kontrol }\end{array}$ & & & & n.s \\
\hline 2017 & Dursun ve Belit & Enerji tasarrufu & 305 & $18 / 61$ ve üzeri & Korelasyon & + \\
\hline 0017 & Kizgin, & $\begin{array}{l}\text { Çevreye duyarlı ürün satın alım } \\
\text { bilinci }\end{array}$ & 230 & $17 / 53$ พӥвагі & $\mathrm{Ki}$ & + \\
\hline 2017 & Örmeci ve Taş & $\begin{array}{l}\text { Çevreye duyarlı ürün kullanım } \\
\text { bilinci }\end{array}$ & 258 & 1//5s ve uzeri & k1-Kare & + \\
\hline & & Ekolojik bilinc & & & & + \\
\hline & & Cevre sorumluluk bilinci & & & & + \\
\hline 2017 & $\begin{array}{l}\text { Göksu, Koska, } \\
\text { Erdem }\end{array}$ & $\begin{array}{l}\text { Çevreye duyarlı ürünleri satın } \\
\text { alma ve kullanma bilinci }\end{array}$ & 385 & $17 / 51$ & Korelasyon & + \\
\hline & & $\begin{array}{l}\text { Geri dönüşümlü ürünleri } \\
\text { kullanma eğilimi }\end{array}$ & & & & + \\
\hline
\end{tabular}


Tablo 1 Devamı: Türkiye'de Yaş-Çevreci Tutum ve Davranış İlişkini İnceleyen Ampirik Araştırma Bulguları

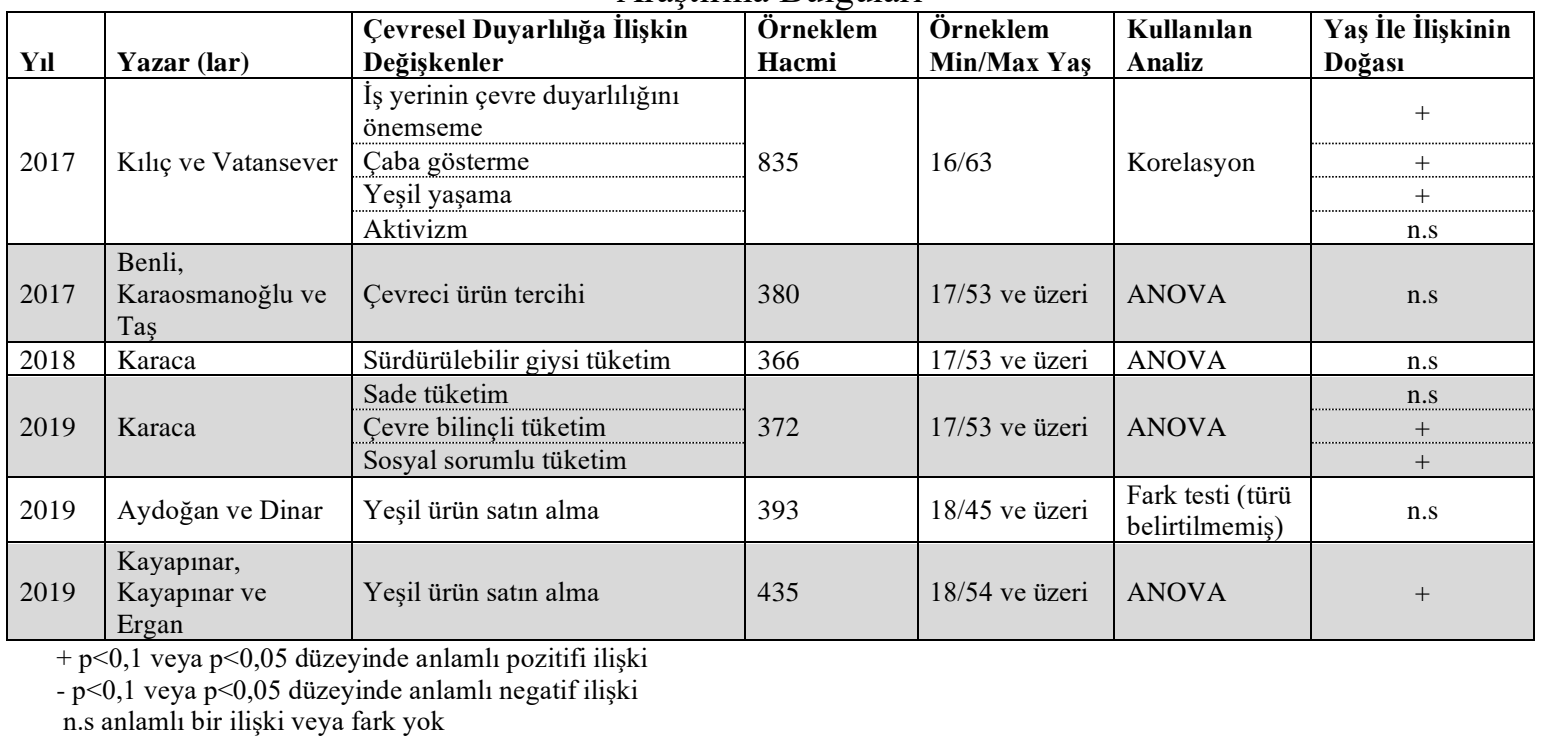

\section{Bulgular ve Değerlendirme}

Türkiye menşeli ulusal araştırma bulguları ağırlıklı olarak, uluslararası araştırmaların 2000 sonrası bulguları ile tutarlı bir şekilde çevreci tutum ve davranışların yaş ile birlikte arttığını göstermektedir. Tablo 1'de görüldüğü gibi araștırmalarda farklı șekillerde kavramsallaştırrlan, işlevselleştirilen genel çevreci tüketim veya enerji tasarrufu, gönüllü sade yaşam gibi özel türdeki çevreci tüketim davranışları çok sayıdaki araştırmada yaş ile pozitif ilişkili olarak bulunmuştur. Bu bulgular, yaşın, ülkemizde sürdürülebilir tüketimi desteklemek için tasarlanan sosyal pazarlama kampanyaları için etkin bölümlendirme kriterlerinden biri olabileceğine işaret etmektedir. Yaș ile çevreci tüketim eğilimleri arasındaki ilişkinin varlığı kadar ilişkinin yönü de sosyal pazarlama kampanyaları açısından oldukça önemlidir. Ulusal literatürdeki bulgulara göre, genç tüketiciler daha ileri yaştakilere oranla daha az çevreci tüketim yapmaktadır. Örgün eğitimleri süresince çevresel sorunlara ilişkin kazanım sağlayacak dersler almalarına, çevreyi korumaya yönelik bilgilendirme kampanyalarına daha fazla maruz kalmalarına rağmen gençlerin çevreci tüketim eğilimlerinin neden ileri yaştaki tüketicilerden daha zayıf olduğunu doğrudan açılayan ampirik bir delile rastlanamamıştır. Ancak yukarıda da değinilen mevcut bulgular çerçevesinde bazı çıkarımlar yapmak mümkündür. Buna göre genç tüketicilerden oluşan hedef kitlenin çevreci tüketim davranışlarının güçlenmesinin önündeki olası engellerden bazıları aşağıda açıklanmıştır.

\section{Daha zayıf altruistik değerler, daha güçlü egoistik değerler}

Çevreci tüketim davranışını açıklamakta sıklıkla kullanılan Değer-İnanç-Norm Teorisi’ne (Stern, Dietz, Abel, Guagnano, ve Kalof, 1999) göre değerler, çevreci davranışların gelişme zincirindeki ilk halkadır ve bireylerin çevreye ilişkin inançlarını, insanoğlu ile doğa arasındaki dengeye yönelik kişisel dünya görüşlerini şekillendirmektedir. Teori, egoistik/öz-genişletim (ör. kendine öncelik verme, keyifçilik) değerlerinin çevreci davranışları zayıflattığını diğer taraftan özaşkınlık değerleri olarak nitelendirilebilecek biyosferik (doğaya, diğer canlılara özen gösterme) ve altruistik (kendisinden başkaları düşünme) değerlerin çevreci davranışları desteklediğini ileri sürmektedir. Önceki bölümlerde özetlenen ulusal ve uluslararası araştırma bulguları incelendiğinde günümüz tüketicilerinin yaşları gençleştikçe hem çevreci tüketim eğilimlerinin hem de çevreci değerlerinin zayıflama gösterdiği anlaşılmaktadır. Örneğin Türk tüketiciler üzerinde yapılan bir araştırma, yaşları gençleştikçe bireylerin öz-aşkınlık değerlerinin zayıfladığını, öz-genişletim 
(egoistik) değerlerinin güçlendiğini göstermektedir (Morsümbül, 2014). Benzer şekilde Aydın (2016) öz-aşkınlık değerlerinin, Özsoy ve Madran (2015) ise çevreci değerlerin daha ileri yaş gurubundaki tüketicilerde gençlerden çok daha güçlü olduğunu göstermiştir. Grønhøj ve Thøgersen (2009), anne-baba ve çocukların çevreci değerlerini karşılaştırdıkları araştırmalarında çocukların ebeveynlerinden çok daha zayıf çevresel değerlere sahip olduğunu göstermiştir. Genç tüketicilerin çevreci, altrusitik değeri zayıflarken, çevreci inançları olumsuz etkileyen materyalist değerlerinde (örn. Kilbourne ve Pickett, 2008) dikkat çekici bir yükseliş olduğuna işaret eden zaman serimli bazı araştırmalar da mevcuttur (Crougiou ve Moschis, 2015). Burada bahsi geçen materyalizm, maddi varlıkları hayatta başarı ve mutluluğun kaynağı olarak görmenin yanında bireysel haz ve keyif kaynaklarına bağl11ı̆̆ da içermektedir (Hellevik, 2002). Bu bulgular 1şığında gençlerin çevreci davranışın kalıcı temellerini oluşturan altruistik, öz-genişletim değerlerinin yeteri kadar güçlü olmadığı sonucuna varmak yanlış olmayacaktır.

\section{Daha zaylf sorumluluk kabulü}

Norm Aktivasyon (Schwartz 1977) ve Değer-İnanç-Norm Teorisi (Stern vd., 1999) çevreci tüketim davranışının sergilenmesinde önemli rol oynayan faktörlerden birinin sorumluluk algısı olduğunu ifade etmektedir. Teorilere göre, tüketicilerin çevresel sorunların meydana gelmesinde etkisi olduğuna inanması ve çözüm için yalnızca başkalarının değil kendisinin de sorumlu olduğunu kabul etmesiyle çevreci tüketim eğilimleri güçlenmektedir. Ancak tüketiciler çevre sorunlarını ve bu sorunların çözümündeki paylarını kolay kolay kabul etmemekte, bireysel sorumluluğun reddi birçok araştırmada sürdürülebilir tüketimin önündeki ana engellerden biri olarak karşımıza çıkmaktadır (örn. Blake, 1999; Lorenzoni, Nicholson-Cole, ve Whitmarsh, 2007; Lorenzoni vd., 2007). Doğrudan bir ampirik bulguya rastlanmamış olsa da yaş-çevreci tüketim ilişkisine dair araştırmalar incelendiğinde genç tüketicilerde bireysel sorumluluğun reddinin nispeten daha fazla olabileceği anlaşılmaktadır. Örneğin Göksu, Koska ve Erdem, (2017), çevre sorumluluk bilincinin yaş düştükçe azaldığını göstermektedir. Benzer bir bulgu Fielding ve Head (2012) tarafından da raporlanmış, yazarlar çevreci davranışları destekleyen sorumluluk hissinin daha genç tüketicilerde daha zayıf olduğunu bulmuştur. Wray-Lake, Flanagan ve Osgood (2010) da 1976-2005 yılları arasında aynı yaştaki genç tüketicilerin çevre sorunlarının çözümü için hissettiği bireysel sorumluluğun düştügünü göstermiştir. Genç tüketiciler çevre sorunlarının çözümü için muhtemelen hükümeti, işletmeleri, diğer tüketicileri (literatür taraması için bakınız Dursun, 2019) veya ebeveynleri sorumlu tutmaktadır.

Teknolojinin içine doğan genç tüketicilerin çevreyi koruma yönünde ileri yaştaki tüketicilere nazaran daha az sorumluluk almalarının bir diğer olası nedeni ise teknolojiye aşırı güvendir. Teknolojiye aşırı güvenme, diğer bir ifadeyle ileri teknolojinin çevre problemleri de dahil olmak üzere bir çok problemi çözeceği inancı, çevreyi korumaya yönelik bireysel çabaların önündeki engellerden biri olarak tanımlanmaktadır (Lorenzoni vd., 2007). Özellikle genç neslin teknolojinin sorunlara çözüm bulacağına dair inancı güçlendikçe daha az kişisel sorumluluk aldıklarına dair bulgular da mevcuttur (Wray-Lake vd., 2010).

Genel olarak değerlendirildiğinde gençlerin çevreci tüketim konusunda daha pasif olmasının nedenlerinden birinin, çevre sorunlarına ilişkin duyarlı olsalar dahi, aktif çabayı beraberinde getirecek sorumluluk duygusunun zayıflığı olduğu ileri sürülebilir.

\section{Çevreci davranışın algılanan maliyetine daha yüksek hassasiyet}

Norm Aktivasyon ve Değer-İnanç-Norm Teorisi'ne göre çevreci tüketim davranışının temel öncülü bireysel normlardır. Altruistik davranma niyeti olarak da nitelendirilebilecek bireysel normlar, başkalarının ve gelecekte yaşayacak insanların da ortak kullanım alanı olan çevreyi korumaya yönelik ahlaki zorunluluk hissini temsil etmektedir (Schwartz 1977; Stern vd., 1999). Ancak genç tüketiciler üzerinde yapılan bazı araştırmalarda bireysel normların belirli çevreci davranışları tetiklemeye yetmediği görülmüştür. Shi, Wang ve Wang, (2019) Pekin'de lisans ve 
lisansüstü öğrenciler üzerinde yaptıkları araştırmada enerji tasarrufuna yönelik normların davranışa dönüşmediğini göstermiştir. Viernik vd. (2013) de yaptıkları meta analizinde genç tüketicilerin çevreyi korumaya yönelik sosyal ve bireysel normlara uymak konusunda daha ileri yaştaki tüketiciler kadar hassas olmadığını, onlar kadar suçluluk ve utanç duyguları ile motive olmadıklarını göstermiştir. Sayıları çok fazla olmasa da bu bulgular akla, ahlaki normların açıklama gücünün zayıflamasina neden olan (örn. Tyler, Orwin ve Schurer, 1982) “yüksek maliyet algısı"nı getirmektedir. Burada bahsi geçen maliyet çevreci tüketim seçeneklerinin maliyetidir ve yalnızca parasal maliyet değil, konfor kaybı, alışılan hayat tarzından vazgeçme, alışkanlıkların değişimi, efor ve zamanı da içine alan, çevreci tüketmemeyi kabul edilebilir kılan mekanizmaları harekete geçirme ve normları etkisizleştirme potansiyeline sahip daha bütüncül bir maliyet kavramıdır.

Gençlerin özellikle algılanan maliyeti yüksek çevreci davranışlarda pasif kaldığını gösteren uluslararası araştırma bulguları, bu tüketici grubunda maliyet hassasiyetlerinin daha yüksek olduğuna yönelik ipuçları sunmaktadır. Örneğin Hellevik (2002), genç tüketicilerin daha ileri yaştakilere oranla çevre sorunlarının daha fazla farkında olduklarını, çevre politikalarına destek gibi aktif olmayan (daha düşük maliyetli) çevreci davranışlarda gönüllü olduklarını ancak günlük aktivitelerinde çevre koruma adına fedakarlık yapma konusunda geride kaldıklarını göstermiştir. Türk tüketiciler üzerinde yapılan araştırmaların sonuçları da, ekonomik fayda sağlama potansiyeli olan israftan kaçınma (Ayten, 2010), gönüllü sade yaşam tarzı (Özgül, 2011), enerji tasarrufu (Dursun ve Belit, 2017) gibi çevreci davranışların gençler tarafından anlamlı şekilde daha az sergilendiğini göstermektedir. Bu durum muhtemelen bu davranışların satın alma alışkanlığını değiştirmeyi, bazı alışkanlıklardan ve yaşam konforundan fedakarlık etmeyi, aktif dikkat ve efor harcamayı gerektirdiğine yönelik inançlar ile ilgilidir. Öyle ki satın alma ve kullanma miktarında azalma gerektirmeyen, yalnızca tercihlerde değişiklik gerektiren çevreci satın alma eğilimlerinde yaş grupları arasında anlamlı bir farklılık olmadığ görülmektedir (Aydoğan ve Dinar, 2019; Zülfikar, 2013; Karaca, 2018; Özdemir, Karaarslan ve Altuntaş, 2010; Şahin, Meral ve Aytop, 2016; Yay ve Çalışkan, 2016). Bu bulgular ışığında çevreci tüketim davranışlarının maddi olmayan maliyetlerinin genç tüketicileri nispeten daha fazla etkilediği, gençlerin hayat kalitelerinin düşmesinden daha fazla endişe ettiği sonucuna varmak mümkündür.

\section{Doğa ile daha az temas}

Gençlerin çevreyi korumaya yönelik çaba sarfetmeleri için doğayı tanımaları ve sevmeleri gerektiğine yönelik bulgular (Palmer, 1993) günümüz gençlerinin çevreci tüketim konusunda neden gönülsüz olduklarını açıklamada faydalıdır. Çevre koruma motivasyonları yüksek katılımcılar üzerinde yapılan araştırmalar, çevreye ilişkin aktif kaygının gelişmesinde tek başına etkili olabilecek en önemli faktörün çocukluk döneminde açık havada, doğada yalnız veya aile ile birlikte vakit geçirilmesi olduğunu göstermiştir (Palmer, 1993; Tanner, 1980). Kals, Schumacher ve Montada (1999) ise bireylerin geçmişte ve daha da önemlisi yaşanan dönemde doğada yaşadığı deneyimlerin doğaya ilgiyi artırdığını, doğayla kurulan duygusal bağı güçlendirdiğini ve çevreyi koruyamamaktan duyulan kızgınlığı artırdığını göstermiştir. Theodori, Luloff, Wdlits ve Willits (1998) de, yaştan ve diğer birçok demografik faktörden bağımsız olarak boş vakitlerinde doğada yürüyüş yapma, kamp kurma, kuş gözlemleme, balık tutma, piknik yapma gibi aktivitelerde bulunan bireylerin çevreyi korumaya yönelik davranışları daha sık gerçekleştirdiğini raporlamaktadır. Doğada vakit geçirmenin bu olumlu etkisi; çevre sorunu örneklerine rastlayarak farkındalığın oluşması, değer verilen alanları koruma isteği yaratması ve doğal çevrenin estetik güzelliğinin kaybolmaması için çevre kirliliğine karş1 olunması yoluyla gerçekleşmektedir (Dunlap ve Heffernan, 1975).

Doğada vakit geçirme ile çevreci davranışlar arasındaki ilişkilere dair bulgular her zaman net olmasa da belirli bir ilişkinin var olduğuna işaret etmektedir (literatür taraması için bakınız Berns ve Simpson, 2009). Bu sebeple, genç tüketicilerin çevreyi koruma yönündeki gönülsüzlükleri, muhtemelen daha ileri yaştaki tüketicilere nazaran doğa ile daha az temas ile büyümeleri, 
çocukluğunda ve şimdiki yaşamında doğada daha az vakit geçirmiş/geçiriyor olmalarının etkisiyle doğa ile güçlü bir bağ kuramamalarıyla açıklanabilir.

\section{Sonuç}

Yakın tarihli ulusal araştırma bulguları değerlendirildiğinde yaşın, sürüdürülebilir/ çevreci tüketim alışkanlıklarının desteklenmesine yönelik sosyal pazarlama kampanyaları için etkili hedef kitle bölümlendirme araçlarından biri olduğu görülmektedir. Ayrıca Türkiye İstatistik Kurumu (TUİK) 2018 verilerine göre toplam nüfusun \%16'sını oluşturan 15-24 yaş grubu çevreci tüketime yönelik sosyal pazarlama kampanyaları için özel bir hedef kitle olarak dikkat çekmektedir. Örgün eğitimleri içinde çevre sorunları ve çözümlerine yönelik çeşitli şekillerde eğitim almalarına, kamu otoritesi, sivil toplum kuruluşları ve işletmeler tarafindan bilgilendirme amacı ile düzenlenen iletişim kampanyalarına maruz kalmalarına rağmen bu genç tüketici grubunun çevreci tüketim eğilimlerinin daha ileri yaşlardaki tüketicilere oranla düşük olduğu görülmektedir. Ancak bu grup aynı zamanda dünya görüşleri, kimlikleri, değerleri ve elbetteki tüketim alışkanlıkları halen değişime açık olan bir gruptur ve bu sebeple sosyal pazarlama kampanyalarının davranış değiştirme potansiyeli oldukça yüksektir. Bu potansiyelin kullanılması için, pazarlama stratejileri geliştirmeden önce bu hedef kitlenin iyi tanınması gereklidir. Ulusal ve uluslararası bulgular kabaca bu hedef kitlenin; (1) geçmişte ve şimdiki zamanda doğa ile nispeten daha az teması bulunduğu için doğa ile duygusal bağ kurmakta zorlanan, (2) daha zayıf altruistik değerlere ancak daha güçlü egoistik ve materyalist değerlere sahip, (3) çevre problemlerinin çözümünde sorumluluğu olduğunu kabul etmek istemeyen, (4) sosyal ve çevreci davranışın getireceği konfor kaybını, ek efor ve zaman gerekliliğini rasyonel bulmayan, (5) bireysel ve sosyal normlardan nispeten daha az etkilenen ve muhtemelen bu sebeplerle çevreci tüketim davranışını benimse(ye)meyen bireylerden oluştuğuna işaret etmektedir. Ancak bu faktörlerin etkilerini bir arada inceleyen ampirik araştırmaların mevcut olmaması nedeni ile kesin bir sonuca varmak mümkün değildir. Diğer taraftan, etkili sosyal pazarlama kampanyaları için bu faktörlerin dışında hedef kitlenin tutum ve davranışlarını etkileyen olası diğer faktörlere yönelik de bilgi sahibi olunması gereklidir. Genç tüketiciler üzerinde yapılacak nitel ve nicel araştırmalarla, bu grup için çevreci tüketim önündeki diğer engellerin, çevreci tüketim davranışlarından beklenen faydaların, motivasyon kaynaklarının, rakip davranış kalıplarının neler olduğunun ve grubu etkileme gücü olan iletişim aktörlerinin kimler olduğunun belirlenmesi önemlidir (Lee ve Kotler, 2016). Ancak bu sayede sosyal değişimin kaynağı olacak genç neslin çevreye zararlı davranışların azaltılması, çevre duyarlı tüketim davranışlarının güçlendirilmesi ve çevreye faydalı yeni tüketim alışkanlıklarının kazandırılması mümkün olacaktır.

\section{Kaynakça}

Aksu, C. K., \& Gelibolu, L. (2015). Üniversite çalışanlarının sürdürülebilir tüketim açısından tutumlarının belirlenmesine yönelik bir araștırma. Kafkas Üniversitesi İktisadi ve İdari Bilimler Fakültesi Dergisi, 6(9): 1309-4289. https://doi.org/10.18025/kauiibf.61831

Andreasen, A. R. (1994). Social marketing: Its definition and domain. Journal of Public Policy \& Marketing, 13(1): 108-114. https://doi.org/10.1177/074391569401300109

Andreasen, A. R. (2002). Marketing social marketing in the social change marketplace. Journal of Public Policy \& Marketing, 21(1): 3-13. https://doi.org/10.1509/jppm.21.1.3.17602

Armağan, E., \& Karatürk, H. E. (2014). Yeşil pazarlama faaliyetleri çerçevesinde aydın bölgesindeki tüketicilerin çevreye duyarlı ürünleri kullanma eğilimlerini belirlemeye yönelik bir araştırma. Organizasyon ve Yönetim Bilimleri Dergisi, 6(1): 1-17.

Aydın, H. (2016). Çevreci tüketicilerin değer temelli bölümlendirilmesi : Çevreci kadın tüketiciler üzerine bir araştırma. Muş Alparslan Üniversitesi Sosyal Bilimler Dergisi, 4(2): 105-124. https://doi.org/10.18506/anemon.258556 
Aydoğan, S. ve Dinar, N. (2019). Yeşil ürün satın almada yeşil reklam ve çevre bilincinin etkisi. The Journal of Academic Social Sciences, 90(90): 229-252. https://doi.org/10.16992/asos.14834

Ayten, A. (2010). 'Sahip olma' mı 'emanet görme” mi? Çevre bilinci ve dindarlık ilişkisi üzerine bir araştırma. Dinbilimleri Akademik Araştırma Dergisi, 10(2): 203-233.

Basil, D. Z., Diaz-Meneses, G., \& Basil, M. D. (2019). Social Marketing in Action, Springer Nature.

Benli, T., Karaosmanoğlu, K., \& Taş, Ö. (2017). Çalışan bireylerin yeşil ürün reklamlarına yönelik tutumlarını etkileyen faktörlerin demografik özelliklerine göre farklılıkları. Business \& Management Studies, 5(4): 235-256. https://doi.org/10.15295/bmij.v5i4.194

Berns, G. N., \& Simpson, S. (2009). Outdoor recreation participation and environmental concern: A research summary. Journal of Experiential Education, 32(1): 79-91. https://doi.org/10.5193/jee.32.1.79

Blake, J. (1999). Overcoming the "value-action gap" in environmental policy: Tensions between national policy and local experience. Local Environment, 4(3): 257-278. https://doi.org/10.1080/13549839908725599

Buttel, F. H. (1979). Age and environemental concern a multivariate analysis. Youth \& Society, 10(3): 237-256. https://doi.org/10.1177/0044118x7901000302

Cheng, H., Kotler, P., \& Lee, N. (Eds.). (2011). Social marketing for public health: global trends and success stories. Jones \& Bartlett Learning.

Crougiou, V., \& Moschis, G. P. (2015). Antecedents of young adults' materialistic values. Journal of Consumer Behaviour, 14: 115-126. https://doi.org/10.1002/cb.1505

Diamantopoulos, A., Schlegelmilch, B. B., Sinkovics, R. R., \& Bohlen, G. M. (2003). Can sociodemographics still play a role in profiling green consumers? A review of the evidence and an empirical investigation. Journal of Business Research, 56(6): 465-480. https://doi.org/10.1016/s0148-2963(01)00241-7

Dunlap, R. E., \& Heffernan, R. B. (1975). Outdoor recreation and environmental concern: An empirical examination. Rural Sociology, 40(1):18.

Dursun, İ. (2019). Psychological barriers to environmentally responsible consumption In I. Altinbasak-Farin \& S. Burnaz (Eds.), Ethics, Social Responsibility and Sustainability in Marketing (pp. 103-128). Springer. https://doi.org/10.1007/978-981-13-7924-6_6

Dursun, İ., \& Belit, M. (2017). Bir sosyal pazarlama hedefi olarak enerji tasarrufu: Tasarruf yöntemleri kullanımınayönelik bir ölçek önerisi. Ömer Halisdemir Üniversitesi İktisadi ve İdari Bilimler Fakültesi Dergisi, 10(3): 130-153. https://doi.org/10.25287/ohuiibf.301050

Dursun, İ., \& Gündüz, S. (2016). Türkiye'de sorumlu tüketim davranışı üzerine araştırmalar: Ulusal makaleler ve lisansüstü tezler üzerine bir derleme. Atatürk Üniversitesi Sosyal Bilimler Enstitüsü Dergisi, 20(4): 1365-1391.

Fielding, K. S., \& Head, B. W. (2012). Determinants of young Australians' environmental actions:The role of responsibility attributions, locus of control, knowledge and attitudes. Environmental Education Research, 18(2): 171-186. https://doi.org/10.1080/13504622.2011.592936

Frame, B., \& Newton, B. (2007). Promoting sustainability through social marketing: Examples from New Zealand. International Journal of Consumer Studies, 31(6): 571-581. https://doi.org/10.1111/j.1470-6431.2007.00600.x

Göksu, N., Koska, A., \& Erdem, M. B. (2017). X ve Y kuşaklarının çevre dostu ürünleri kullanım eğilimleri. Siyaset, Ekonomi ve Yönetim Araştırmaları Dergisi, 5(3): 109-122. 
Grønhøj, A., \& Thøgersen, J. (2009). Like father, like son? Intergenerational transmission of values, attitudes, and behaviours in the environmental domain. Journal of Environmental Psychology, 29(4): 414-421. https://doi.org/10.1016/j.jenvp.2009.05.002

Hellevik, O. (2002). Beliefs, attitudes and behaviour towards the environment. In W. M. Lafferty, M. Nordskag, ve H. A. Aakre (Eds.), Realizing Rio in Norway Evaluative Studies of Sustainable Development (pp. 7-20). Oslo: Program for Research and Documentation for a Sustainable Society (ProSus).

Hines, J. M., Hungerford, H. R., \& Tomera, A. N. (1987). Analysis and synthesis of research on responsible environmental behavior: A meta-analysis. Journal of Environmental Education, 18(2): 1-8.

Honnold, J. A. (1984). Age and environmental concern some specification of effects. Journal of Environmental Education, 16(1): 4-9.

Johnson, C. Y., Bowker, J. M., \& Cordell, H. K. (2004). Ethnic variation in environmental belief and behavior: An examination of the new ecological paradigm in a social psychological context. Environment and Behavior, 36: 157-186. https://doi.org/10.1177/0013916503251478

Kals, E., Schumacher, D., \& Montada, L. (1999). Emotional affinity toward nature as a motivational basis to protect nature. Environment and Behavior, 31(2): 178-202. https://doi.org/10.1177/00139169921972056

Karaca, Ş. (2013). Tüketicilerin yeşil ürünlere ilişkin tutumlarının incelenmesine yönelik bir araştırma. Ege Akademik Bakış, 13(1): 99-111. https://doi.org/10.21121/eab.2013119503

Karaca, Ş. (2018). Duygusal ve bilişsel güdülerin sürdürülebilir giysi tüketim davranışı üzerindeki etkisini incelemeye yönelik bir çalışma. Selçuk Üniversitesi Sosyal Bilimler Enstitüsü Dergisi, (40): 254-268.

Karaca, Ş. (2019). Bireysel sosyal sorumluluğun bilinçli tüketim davranış1 üzerindeki etkisini incelemeye yönelik bir çalışma. Dokuz Eylül Üniversitesi Sosyal Bilimler Enstitüsü Dergisi, 21(1): 147-172. https://doi.org/10.16953/deusosbil.439642

Kılıç, N., \& Vatansever, Ç. (2017). Çalışanların yeşil tutum ve davranışları ile yaşam değerleri ilişkisi. In T. Turgut ve M. Çinko (Eds.), Değerli İnsana "Değer"i Çalışmalar: Yaşam Ve Çalışma Değerleri Üzerine Araştırmalar (pp. 201-228).

Kızgın, Y., Karaosmanoğlu, K., Örmeci, G., \&Taş, Ö. (2017). Tüketicilerin sürdürülebilir tüketim bağlamında yeşil tüketim eğilimleri ve demografik özelliklere göre farklılıkları. 1st International Sustainable Tourism Congress / November 23-25, 2017 / Kastamonu-Turkey

Kilbourne, W. E., \& Beckmann, S. C. (1998). Review and critical assessment of research on marketing and the environment. Journal of Marketing Management, 14(6): 513-532. https://doi.org/10.1362/026725798784867716

Kilbourne, W., \& Pickett, G. (2008). How materialism affects environmental beliefs, concern, and environmentally responsible behavior. Journal of Business Research, 61(9): 885-893. https://doi.org/10.1016/j.jbusres.2007.09.016

Kotler, P. (1999). Marketing management: The millennium edition. Prentice Hall.

Kotler, P., \& Levy, S. J. (1969). Broadening the concept of marketing. Journal of marketing, 33(1): 10-15. https://doi.org/10.1177/002224296903300103

Kotler, P., \& Zaltman, G. (1971). Social marketing: an approach to planned social change. Journal of marketing, 35(3): 3-12. https://doi.org/10.1177/002224297103500302

Lee, N. R., \& Kotler, P. (2016). Social marketing: Changing behaviors for good. Sage Publications. 
Lefebvre, R. C. (2013). Social marketing and social change: Strategies and tools for improving health, well-being, and the environment. John Wiley \& Sons.

Lorenzoni, I., Nicholson-Cole, S., \& Whitmarsh, L. (2007). Barriers perceived to engaging with climate change among the UK public and their policy implications. Global Environmental Change, 17(3-4): 445-459. https://doi.org/10.1016/j.gloenvcha.2007.01.004

MacFadyen, L., Stead, M., \& Hastings, G. (1999). A synopsis of social marketing. Institute for Social Marketing, 1-10.

McKenzie-Mohr, D. (1994). Social marketing for sustainability. Futures, 26(2): 224-233. https://doi.org/10.1016/0016-3287(94)90111-2

McKenzie-Mohr, D. (2000). Promoting sustainable behavior: An introduction to communitybased social marketing. Journal of Social Issues, 56(3): 543-554. https://doi.org/10.1111/00224537.00183

Morsümbül, Ş. (2014). Değerlerin Kuşaklar Arası Değişimi: Ankara Örneği. Yayınlanmamış Doktora Tezi, Hacettepe Üniversitesi Sosyal Bilimler Enstitüsü, Ankara.

Nakiboğlu, B. (2007). Tüketimin çevreci boyutu: çevreci tutum ve davranışlara göre pazar bölümlemesi. Ç.Ü. Sosyal Bilimler Enstitüsü Dergisi, 16(2): 423-438. https://doi.org/10.35379/cusosbil.634679

Olli, E., Grendstad, G., \& Wollebaek, D. (2001). Correlates of environemental behaviors. Bringing back social context. Environment and Behavior, 33(2): 181-208. https://doi.org/10.1177/00139160121972945

Ostman, R. E., \& Parker, J. L. (1987). Impact of education, age, newspapers, and television on environmental knowledge, concerns, and behaviors. Journal of Environmental Education, 19(1): 3-9. https://doi.org/10.1080/00958964.1987.10801954

Özdemir, H. Ö., Karaarslan, M. H., \& Altuntaş, B. (2010). Tüketicilerin çevreci işletmelere ve ürünlere karşı tutumları: Ankara, İstanbul ve Kırşehir illerinde bir uygulama. E-Journal of New World Sciences Academy, 5(4): 1-9.

Özgül, E. (2011). Tüketicilerin sosyo-demografîk özelliklerinin hedonik tüketim ve gönüllü sade yaşam tarzları açısından degerlendirilmesi. Ege Akademik Bakış, 11(1): 25-38. https://doi.org/10.21121/eab.2011119578

Özsoy, T., \& Madran, C. (2015). Ürün ömrü algısının sürdürülebilir tüketim boyutundan bir analizi. Global Journal of Economics and Business Studies, 4(7): 73-91.

Palmer, J. A. (1993). Development of concern for the environment and formative experiences of educators. Journal of Environmental Education, 24(3): 26-30.

Peattie, K. (2012). Researching the unselfish consumer. in Victoria Wells and Gordon Foxall (ed.), Handbook of Developments in Consumer Behavior. Edward Elgar Publishing. https://doi.org/10.4337/9781781005125.00013

Şahin, A., Meral, H., \& Aytop, Y. (2016). Yeşil pazarlamada tüketici algısı: Kahramanmaraş kent merkezi örneği. Anadolu Journal of Agricultural Sciences, 31(1): 60. https://doi.org/10.7161/anajas.2016.31.1.60-71

Schwartz, S. H., (1977). Normative influences on altruism. In L. Berkowitz (Ed.), Advances in Experimental Social Psychology (Vol. 10, pp. 221-279). Academic Press. https://doi.org/10.1016/s0065-2601(08)60358-5

Shi, D., Wang, L., \& Wang, Z. (2019). What affects individual energy conservation behavior: Personal habits, external conditions or values? An empirical study based on a survey of 
college students. Energy Policy, 128 (November 2018): 150-161. https://doi.org/10.1016/j.enpol.2018.12.061

Stern, P. C., Dietz, T., Abel, T., Guagnano, G. A., \& Kalof, L. (1999). A value-belief-norm theory of support for social movements: The case of environmentalism. Human Ecology Review, 6(2): 81-97.

Tanner, T. (1980). Significant life experiences: a new research area in enviromental education. The Journal of Environmental Education, 11(11): 20-24. https://doi.org/10.1080/00958964.1980.9941386

Theodori, G. L., Luloff, A. E., Wdlits, F. K., \& Willits, F. K. (1998). The association of outdoor recreation and environmental concern: Reexamining the Dunlap-Heffernan thesis. Rural Sociology, 63(1): 94-108. https://doi.org/10.1111/j.1549-0831.1998.tb00666.x

TUIK (2018). Türkiye İstatistik Kurumu, 2018 Adrese dayalı nüfus kayıt sistemi istatitikleri, http://tuik.gov.tr/PreIstatistikTablo.do?istab_id=945 28.11.2019

Tyler, T. R., Orwin, R., \& Schurer, L. (1982). Defensive denial and high cost prosocial behavior. Basic and Applied Social Psychology, 3(4): 267-281. https://doi.org/10.1207/s15324834basp0304_4

Van Liere, K., \& Dunlap, R. (1980). The social bases of environmental concern: A review of hypotheses, explanations and empirical evidence. The Public Opinion Querterly, 44(2): 181197. https://doi.org/10.1086/268583

Yaraş, E., Akın, E., \& Şakacı, B. K. (2011). Tüketicilerin çevre bilinci düzeylerini belirlemeye yönelik bir araştirma. Öneri Dergisi, 9(35): 117-126.

Yeşilada, F. (2009). Kuzey Kıbrıs Türk Cumhuriyeti'nde çevre bilinçli tüketicilerin profili. Yakın Doğu Üniversitesi Ikktisadi ve İdari Bilimler Fakültesi Dergisi, 10(1): 79-95.

Yürük-Kayapınar, P., Kayapınar, Ö., \& Ergan, S. (2019). Tüketicilerin yeşil ürün satın alma davranışlarının kuşaklar bakımından incelenmesi. OPUS Uluslararası Toplum Araştırmaları Dergisi, 11(18): 2056-2070. https://doi.org/10.26466/opus.565155

Wells, V. K., Ponting, C. A. ve Peattie, K. (2011). Behaviour and climate change: Consumer perceptions of responsibility. Journal of Marketing Management, 27(7-8): 808-833. https://doi.org/10.1080/0267257x.2010.500136

Wiernik, B. M., Ones, D. S., \& Dilchert, S. (2013). Age and environmental sustainability: A metaanalysis. Journal of Managerial Psychology, 28(7): 826-856. https://doi.org/10.1108/jmp07-2013-0221

Wray-Lake, L., Flanagan, C. A., \& Osgood, D. W. (2010). Examining trends in adolescent environmental attitudes, beliefs, and behaviors across three decades. Environment and Behavior, 42(1): 61-85. https://doi.org/10.1177/0013916509335163

Yay, Ö., \& Çalışkan, O. (2016). Planlı davranış teorisi bağlamında çevreci otel restoranında yemek yeme niyeti. Seyahat ve Otel İşletmeciliği Dergisi, 13(2): 103-122. https://doi.org/10.24010/soid.562353

Zülfikar, H. (2013). Hanelerin yeşil ürün ve hizmet tercihlerinde etkin unsurlar üzerine bir inceleme. Sosyoloji Konferanslarl, O(48): 57-73. 